\title{
Aydın Illinde Karpuz Fusarium Solgunluğu Hastalığının Yaygınlık ve Bulunma Oranı
}

\section{Birsen GEÇiOĞLU ERINCiK*'(D), Mustafa Timur DÖKEN²[D}

\author{
' Adnan Menderes Üniversitesi, Koçarlı Meslek Yüksekokulu, Aydın. \\ ${ }^{2}$ Adnan Menderes Üniversitesi, Ziraat Fakültesi, Bitki Koruma Bölümü, Aydın.
}

Öz: Dünyada karpuz üretimini sınırlayan faktörlerin bașında Fusarium Solgunluğu hastalığı gelmektedir. Aydın ilinde karpuzlarda kurumalar yaygın olarak görülmekte olup bu kurumaların Fusarium Solgunluğu ile ne denli ilișkili olduğu bilinmemektedir. Çalıșmamızda Aydın ve ilçelerindeki karpuz üretim alanlarında kuruma ve solgunluk yaygınlı̆ını ve bulunma oranını belirlemek amacıyla 2010 ve 201 I yıllarında sörveyler gerçekleștirilmiștir. Aydın genelinde 17 ilçe gezilmiș ve hastalık belirtisi gösteren bitkilerden toplam 470 örnek toplanmıștır. Sörvey sonuçlarına göre hastalık görülen ilçelerde hastalık yaygınlığının \%45-100 arasında değiștiği belirlenmiștir. İzolasyonlardan 185 adet Fusarium spp. izolatı elde edilmiștir. Patojenisite ve takiben tanılama çalıșmaları sonucunda 73 adet izolat Fusarium oxysporum f.sp. niveum (FON) olarak tanılanmıștır. FON izolatlarının elde edildiği 45 tarlada karpuzda Fusarium solgunluğunun bulunma oranı \%0.17-12 arasında saptanmıștır.

Anahtar Kelimeler: Fusarium oxysporum f.sp. niveum, toprak kaynaklı patojen, Cucurbitaceae, sörvey

\section{Prevalence and Incidence of Fusarium Wilt of Watermelon in the Aydın Province}

Abstract: Fusarium wilt is a major limiting factor in the commercial watermelon production areas in the world. In Aydin Province, the vine death in watermelons occurs commonly, but engagement of Fusarium wilt in the occurrence of these deaths have still unknown. In this study, the field surveys were conducted to determine prevalence and incidence of Fusarium wilt in the watermelon producing counties of Aydin Province in 2010-20II. In I7 counties, 470 samples were collected from the plants exhibiting disease symptoms. The surveys revealed that the disease prevalence in the counties ranged from $45 \%$ to $100 \%$. A total of 185 Fusarium spp. isolates were recovered from the isolations. As a result of pathogenicity and identification studies, 73 isolates were identified as Fusarium oxysporum f.sp. niveum (FON). In the 45 fields where the FON isolates were found, the incidence of Fusarium wilt ranged from $0.17 \%$ to $12 \%$.

Keywords: Fusarium oxysporum f.sp. niveum, soil-borne pathogen, Cucurbitaceae, survey

\section{GiRiș}

Dünyada milyonlarca hektar üretim alanı ile en yaygın sebzeler içerisinde yer alan karpuzun [Citrullus lanatus var. lanatus (Thunb.) Matsum. \& Nakai] varlığı ve üretimi 1800 'lü yılların sonlarına doğru Fusarium solgunluğu nedeni ile olumsuz yönde etkilenmeye bașlamıștır. Fusarium oxysporum f. sp. niveum (E.F. Sm.) Snyd. \& Hans. (FON) adlı bir fungal etmenin neden olduğu bu hastalık önce Amerika'da, daha sonra da Asya ve Avrupa'da karpuz üretim alanlarında büyük çapta tahribat olușturmuștur (Martyn ve McLaughlin, 1983).

Toprak kökenli bir hastalık etmeni olan FON optimum $20-27^{\circ} \mathrm{C}$ sıcaklıkta bulunan ve nem oranı \%25' den düșük ve pH'sı 5.5- 6.5 olan hafif kumlu, yüksek nitrojen içeren topraklarda çok daha yaygın olarak görülmektedir (Martyn, 1996). Hastalığın tarla içerisinde ve tarladan tarlaya yayılması bulașık toprağın çiftlik ekipmanları, toprak ișleme, sulama, rüzgar, sel baskını, așırı yağıș, hayvanlar gibi kültürel ve çevresel faktörler tarafından tașınması ile gerçekleșmektedir (Ferreira ve Boley, 1991). Hastalığın uzun mesafelere tașınımasından enfekteli üretim materyalleri sorumludur. Hastalık tohumla da tașınabilmektedir (Kuniyasu, 1980).

Karpuz Fusarium solgunluğu, karpuz üretilen alanlarda bitkinin tüm gelișme dönemlerinde ortaya çıkabilir. Hastalığın ilk belirtileri, öncelikle yapraklarda ortaya çıkan soluk, gri-yeșil renk olușumudur. Bu belirtileri, genellikle kök boğazına yakın yașlı yapraklarda bașlayan ve uçlara doğru ilerleyen yaprak sararmaları takip eder. Daha sonra bu yapraklar hızla suyunu kaybeder, 2-3 gün içerisinde de solar ve kururlar (Martyn, 1996). Illk belirtilerin bașlangıcı bitkinin kol atmaya bașladığı dönem olup solgunluk bir kolda bașlar, diğer kollar ise genellikle sağlıklı görünür. İnokulum yoğunluğunun yüksek ve konukçu bitkinin duyarı olduğu durumlarda bitki kısa süre içinde ölebilir. Hastalıktan etkilenen ancak ölmeyen bitkiler ise küçük kalır, verimde önemli oranda azalma meydana gelir. Fusarium solgunluğunun en güvenilir ve doğru tanı belirtisi, iletim demetlerinde ortaya çıkan kahverengileșmedir (Egel ve Martyn, 2007).

Birçok yöresi iklim ve toprak özellikleri bakımından karpuz yetiștiriciliği için uygun olan ülkemizde de Fusarium solgunluğu ilk kez 1965 yılında Marmara Bölgesinde saptanarak karpuzda \%50' den fazla zarar yaptığı bildirilmiștir (Akdoğan, 1969). Daha sonra Ege Bölgesinde, İzmir, Manisa, Aydın illerinde belirlenen bu hastalığın (Bora ve Özkut, 1972; Karaca ve Qureshi, 1979; Qureshi ve Yıldız, 1982; Filiz ve Turhan, 1991), Doğu Akdeniz ve Güneydoğu Anadolu Bölgelerinde de bulunduğu (Yücel ve ark., 1999; Kurt ve ark., 2005) ve bu bölgelerde ciddi ekonomik kayıplara neden olduğu saptanmıștır.

Verdiğimiz kaynak bilgilerinden de anlașılacağı üzere Aydın ve ilçelerinde karpuz Fusarium solgunluğu ile ilgili çok az bilgi bulunmaktadır. Bu nedenle de hastalığın günümüzdeki yaygınlık ve bulunma oranının ne olduğu, karpuz üretiminde ne derecede etkili olduğu hakkında bir yorum yapmak mümkün değildir. Yaptığımız bu çalıșmada Aydın ili karpuz üretim alanlarındaki kurumaların ve Fusarium solgunluğunun gerçek boyutlarının ortaya konulması hedeflenmiștir.

Sorumlu Yazar: bgerincik@adu.edu.tr

Bu çalıșma doktora tezi ürünü olup, Adnan Menderes Üniversitesi Bilimsel Araștırma Projeleri ZRF-I 20 I I no'lu proje kapsamında desteklenmiștir.

Geliş Tarihi: 15 Ocak 2018

Kabul Tarihi: 31 Mayıs 2018 


\section{MATERYAL ve YÖNTEM}

\section{Sörvey Çalıșmaları}

Türkiye İstatistik Kurumunun (TÜiK) 2008 ve 2009 yılı verilerine göre (Anonim, 2009) Aydın ili ve ilçelerindeki karpuz üretiminin yapıldığı belirtilen ilçelerin tamamı (Merkez, Bozdoğan, Buharkent, Çine, Didim, Germencik, İncirliova, Karacasu, Karpuzlu, Koçarlı, Köșk, Kușadası, Kuyucak, Nazilli, Söke, Sultanhisar, Yenipazar) 20I0-20II yıllarında gezilerek karpuz üretim alanları incelenmiș ve hastalığın yaygınlığı belirlenmiștir.

Hastalığın yaygınlığını belirlemek amacıyla üretim alanlarındaki karpuz bitkileri solgunluk hastalığı simptomları olan yeșil aksamının tamamında ya da bir tarafında solgunluk ve/veya iletim demetlerinde kahverengileșmeler yönünden incelenerek tarlalarda hastalığın olup olmadığı saptanmıștır. Hastalık yaygınlığı incelenen tarlalar arasında hastalığın görüldüğü tarlaların oranı (\%) olarak belirlenmiștir. Hastalığın bulunma oranı ise yine TÜiK'in 2008 ve 2009 yılı verilerine göre 1000 tonun üzerinde karpuz üretimi yapıldığı belirtilen ilçelerden Çine, Koçarlı, Söke, Sultanhisar, Merkez, Bozdoğan, Nazilli, İncirliova'da belirlenmiștir. Aynı yıla ait verilere göre karpuz üretiminin 1000 tonun üzerinde olduğu belirtilen ilçeler arasında yer alan Köșk ilçesinde yapılan sörveylerde tek bir tarla tespit edilmesi ve bu tarlada da hastalıklı bitki görülmemesi, Karpuzlu ilçesinde ise karpuz üretimi yapılan tarlanın bulunamaması nedeniyle bu iki ilçede hastalığın bulunma oranı saptanamamıștır. Bulunma oranı hastalıklı bitkilerin oranı (\%) olarak hesaplanmıștır. Değerlendirilmeye alınan bitki sayısı tarla büyüklüğüne bağlı olarak bitkilerin \%2-10 arasında değișmiș olup șansa bağlı seçilen 20'li gruplar içinde bitkiler hasta ve sağlıklı olarak kaydedilmiștir.

\section{İolatların Elde Edilmesi}

Sörveyler sırasında izolasyon çalıșmalarında kullanılmak üzere hastalıklı bitki örnekleri de alınmıștır. Örnekler tarladaki hastalık bulunma oranına bağlı olarak tipik solgunluk belirtisi sergileyen bitkilerden rastgele seçilerek topraktan sökülmüștür. Bu bitkilerin kök boğazından itibaren yaklașık $10 \mathrm{~cm}$ yukarıda kalan yeșil aksamı kesilerek atılmıș, kalan kısmı kese kağıdı içinde laboratuvara getirilerek izolasyona kadar $4^{\circ} \mathrm{C}$ de buzdolabında saklanmıștır. 2010 yılında incelenen karpuz üretim alanlarından yaklașık I 20 adet, 201 I yılında incelenen alanlardan da yaklașık 350 adet olmak üzere toplam 470 bitki örneği çalıșmamızın ana materyali Fusarium Solgunluğu etmenini elde etmek amacıyla toplanmıștır. İzolasyon için laboratuvara getirilen bitki örnekleri, çeșme suyu altında yıkandıktan sonra kök ve kök boğazından parçalar alınarak \%5'lik sodyum hipoklorit içinde 2 dakika süre ile yüzeysel olarak dezenfekte edilmiștir. Daha sonra 2 defa steril damıtık suda durulanıp takiben steril filitre kağıtları arasında kurutulmuștur. Örnekler petri kaplarında bulunan 50 $\mathrm{mgL}^{-1}$ streptomycin sulfate içeren patates dekstroz agar (PDA) besiyeri üzerine konularak $27^{\circ} \mathrm{C}$ de karanlıkta 2-3 gün inkübe edilmiștir. İnkübasyondan sonra izolatların koloni morfolojileri incelenmiș ardından Fusarium oxysporum'un tipik kültürel özelliklerini tașıdığı gözlemlenen izolatların mikroskobik (makrokonidi, mikrokonidi) özellikleri de incelenmiștir. Oval ya da böbrek șeklinde mikrokonidi ve/veya kıvrık, kano șeklinde makrokonidilere sahip, bașlangıçta beyaz daha sonra pembeden mora kadar değișen koloniler seçilip, tekrar aynı konsantrasyonda antibiyotik ilave edilmiș PDA besi ortamına aktarılarak inkubasyona alınmıșlardır (Leslie ve Summerell, 2006). İzolasyon çalıșmaları sonucu Fusarium oxysporum olduğu düșünülen 185 adet Fusarium spp. izolatı elde edilmiștir.

\section{İzolatların Patojenisitelerinin Belirlenmesi}

Fusarium oxysporum f.sp. niveum (FON)'un izolatlarını belirlemek için kültürel ve morfolojik özelliklerine göre $F$. oxysporum olabileceği varsayılan 185 adet Fusarium spp. izolatının tek sporları ile patojenisite testi yapılmıștır. Bu test, spor süspansiyonuna daldırma yöntemine göre gerçekleștirilmiștir (Latin ve Snell,1986). Izolatlar oda sıcaklığında 12 saat ıșık periyodunda 5-6 gün süreyle 128 rpm' de çalıșan çalkalayıcıda Patates Dextroz Broth (PDB) besi ortamında geliștirilmiștir. Gelișen kültürler 4 katlı tülbentten süzülerek her bir kültür için mikrokonidi süspansiyonu elde edilmiștir. Mikrokonidi süspansiyonun konsantrasyonu hemositometre ile ölçülerek $10^{6}$ mikrokonidi/ml olacak șekilde ayarlanmıștır. Bu testte FON'un tüm ırklarına duyarlı olduğu bilinen Sugar Baby karpuz çeșiti (Zhou ve ark., 20I0) kullanılmıștır. Karpuz fideleri yaklașık iki haftalık iken yani ilk gerçek yaprak dönemi geldiğinde viyollerden çıkarılmıș ve kökleri akan suyun altında yıkanarak toprağından temizlenmiștir. Takiben bitki köklerinin boyu aseptik koșullarda makasla kesilmek suretiyle kısaltılmıș ve hazırlanan süspansiyon içinde I-2 dk bekletilerek inokule edilmișlerdir. Süspansiyon içerisinden çıkarılan fideler içerisinde steril toprak-torf-perlit karıșımı bulunan $15 \mathrm{~cm}$ çapındaki saksılara șașırtılmıștır. Bitkiler iklim odasında $24^{\circ} \mathrm{C}$ de 14 saat aydınlık 10 saat karanlık koșullarda 2 gün süre ile inkübasyona bırakılmıș ve takiben kontrollü seraya tașınmıșlardır. Sera koșulları gündüz yaklașık $30^{\circ} \mathrm{C}$ (I4 saat aydınlık), gece yaklașık $18^{\circ} \mathrm{C}$ (I0 saat karanlık) olacak șekilde ayarlanmıștır. Bitkiler bu koșullardaki gelișme süreci içinde yapraklarında sararma ve solgunluklar yönünden gözlemlenmiștir. Bitkilerde hastalık gelișimi değerlendirmesi inokulasyondan yaklașık bir ay sonra yapılmıștır. Değerlendirme bitkinin gövdesi kök boğazından itibaren dikine kesilerek ve iletim demetlerindeki kahverengileșen bölgenin boyuna uzunluğu (mm) ölçülerek yapılmıștır. Bu çalıșma üç yinelemeli olarak yapılmıș olup, her bir tekerrür için 3-6 fide kullanılmıștır. Kontrol bitkilerine ise steril saf su inokule edilmiștir. İzolatların patojenisiteleri, iletim demetlerindeki nekrozların (kahverengileșme) uzunluğu baz alınarak hazırladığımız skalaya (Geçioğlu Erincik ve Döken, 2017) göre ölçülmüș (Çizelge I) ve elde edilen skala değerleri Tawsend-Heuberger formülü uygulanarak F. oxysporum izolatlarının hastalık yüzdeleri (hastalık șiddeti) hesaplanmıștır. Ölü bitkilere en üst skala değeri olan "5" değeri verilmiștir. İletim demetlerinde kahverengileșmeye neden

Çizelge I. Hastalık ölçümünde kullanılan karpuz kök boğazı ve gövdesinde olușan nekroz uzunluklarının skala değerleri

\begin{tabular}{cc}
\hline Skala Değerleri & Nekroz Uzunlukları (Kahverengileșmenin Boyuna Uzunluğu) \\
\hline 0 & Kahverengileșme yok \\
1 & $1-15 \mathrm{~mm}$ \\
2 & $16-30 \mathrm{~mm}$ \\
3 & $31-45 \mathrm{~mm}$ \\
4 & $46-60 \mathrm{~mm}$ \\
5 & $\geq 60 \mathrm{~mm}$ yada bitki tamamen solmuș (ölmüș) \\
\hline
\end{tabular}


olmayan izolatlar değerlendirilmeye alınmamıștır.

\section{Fusarium oxysporum İzolatlarının Tanılanması}

Patojenisite testi sonucu karpuz bitkilerinde hastalık yapan izolatlarda, patojenin Fusarium oxysporum tanısı Carnation Leaf Agar (CLA) ortamında gelișen etmenin morfolojik yapıları incelenerek belirlenmiștir. Patojenisite testi sonucu seçilen tek sporları elde edilmiș 75 Fusarium spp. izolatının CLA' ya ekimleri yapılmıș ve $25^{\circ} \mathrm{C}$ 'de 4 hafta inkubasyona bırakılmıștır. Daha sonra bu izolatlar mikroskopta 40x objektif altında makrokonidi, mikrokonidi, klamidospor, konidiofor ve fialid özellikleri dikkate alınarak incelenmiș ve izolatların 73 adeti Fusarium oxysporum olarak tanılanmıștır. F. oxysporum tanısı kısa monofialidler üzerinde oval ya da böbrek șeklinde mikrokonidilerin yanı sıra 3-5 hücreli kıvrık, kano șeklinde makrokonidi varlığı ile hifin uç kısmında ya da ortasında klamidospor olușumuna (Leslie ve Summerell, 2006) dayanarak yapılmıștır.

\section{İzolatların Bazı Kabakgillerde Patojenisitelerinin Belirlenmesi}

Fusarium oxysporum forma speciales'leri konukçuya özelleșmiș olup, enfekte ettikleri konukçu türlerine göre adlandırılmakla birlikte bazı forma speciales'lerin sera ve laboratuvar koșullarında diğer kabakgilleri de enfekte ettiği yani çapraz enfeksiyonların olușabildiği bildirilmektedir (Egel ve Martyn, 2007; Zhou ve Everts, 2007). Bu nedenle patojenisite testleri sonuçlarına ve takiben CLA'da geliștirilen izolatların mikroskobik özelliklerine dayanarak FON olduğu belirlenen 73 adet izolatın diğer kabakgiller olan hıyar, kavun ve kabak bitkilerinde de patojen olup olmadığı testlenmiștir. Böylece karpuzu hastalandıran izolatlarımız arasında diğer kabakgilleri hastalandıran forma specialis'lerin olup olmadığı ortaya konmuștur. FON izolatlarının patojenisitelerinin belirlenmesinde açıklandığı gibi uygulanan bu testte Fusarium oxysporum forma speciales'lerine hassas olduğu bilinen kabakta Sakız, kavunda Ananas, hıyarda Çengelköy çeșitleri kullanılırken, kontrol olarak karpuzda ise yine Sugar Baby çeșiti kullanılmıștır. İnokulasyonun ardından bitkiler gelișme süreci içinde yapraklarında sararma ve solgunluklar yönünden gözlemlenmiștir. Ayrıca inokulasyondan yaklașık bir ay sonra bitkinin kök ve kök boğazında nekrotik lezyonların varlığı, iletim demetlerindeki kahverengileșmelerin olup olmadığı belirlenmiștir. Bitkilerde hastalık gelișiminin değerlendirilmesi de yine izolatların patojenisitelerinin belirlenmesindeki gibi planlanmıștır.

\section{BULGULAR ve TARTIȘMA \\ Aydın İli Karpuz Üretim Alanlarında Solgunluk ve Kurumaların Yaygınlığı}

Aydın ilinin karpuz üretim alanlarındaki solgunluk ve kurumaların yaygınlığının ve bulunma oranlarının belirlenmesi amacıyla 2010 yılında Temmuz-Ağustos aylarında 29 karpuz üretim alanında (yaklașık $425 \mathrm{da}$ ), 20II yılında ise Haziran-Eylül aylarında 103 karpuz üretim alanında (yaklașık 1026 da) incelemeler yapılmıștır. İki yılda il genelinde on ilçede (Merkez, Çine, Koçarlı, Bozdoğan, Söke, Sultanhisar, Yenipazar, Nazilli, İncirliova ve Köșk) incelenen toplam I 32 tarladan 80 (\%60.6)'inde solgunluk ve kuruma belirtisi gösteren karpuz bitkileri saptanmıștır. Bu belirtileri gösteren karpuz bitkilerinin bulunduğu ilçelerde hastalık yaygınlığı \%45 ile \% I00 arasında değișmiștir (Çizelge 2). Incelenen ilçeler arasında solgunluk ve kuruma en yaygın olarak Koçarlı ilçesinde saptanmıștır. Aydın'da karpuz üretiminde önde gelen ilçelerden biri olan bu ilçede incelenen 29 tarladan

Çizelge 2. 20 10- 201 I yıllarında Aydın ili karpuz ekim alanlarında yapılan sörveylerde saptanan karpuz kurumalarının yaygınlığı

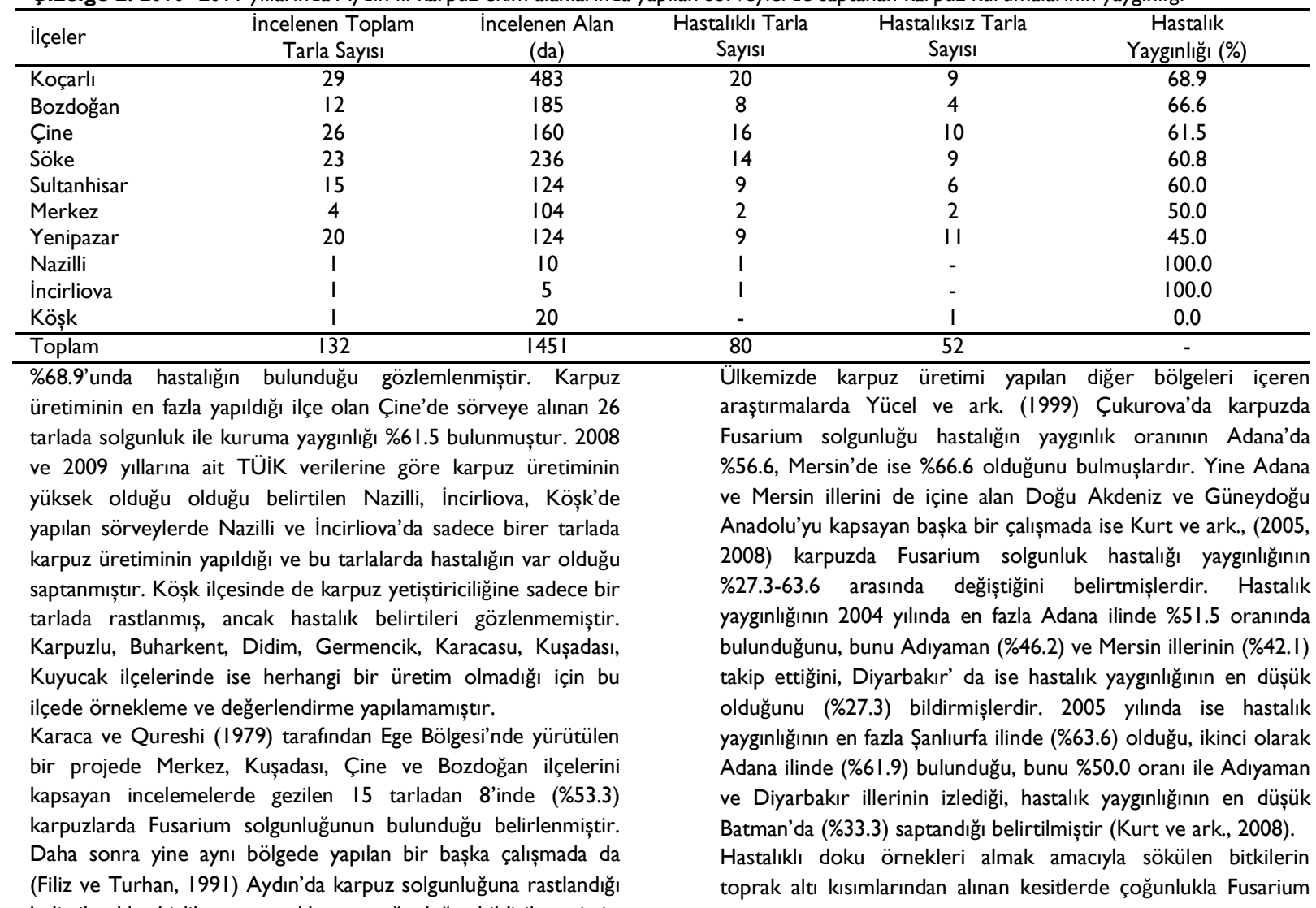


solgunluğunun tipik belirtisi olan iletim demetlerinde kahverengileșmeler gözlenmiștir. Ancak kök ile kök boğazı kısımlarında diğer toprak kökenli patojenlerin de neden olabildiği kuru ve yumușak çürüklük belirtilerini gösteren bitkilerin varlığına da rastlanmıștır. Bu nedenle tarla incelemeleri sırasında saptanan solgunluk ve kurumalar doğrudan Fusarium solgunluğu ile ilișkilendirilmemiștir.

\section{Fusarium spp. İzolatların Patojenisiteleri}

Kuruma ve solgunluk belirtisi gösteren 470 adet karpuz bitkisinden alınan örneklerden yapılan izolasyonlar sonucunda Fusarium spp.'ye özgü kültürel özelliklere sahip olan 230 adet koloni seçilmiștir. Daha sonra bu izolatların morfolojik özellikleri mikroskobik olarak incelenerek 185 izolatın Fusarium oxysporum olabileceği varsayımı ile patojenisitelerinin yapılmasına karar verilmiștir. Sugar Baby karpuz çeșidine ait fideler üzerinde yapılan patojenisite testleri sonucunda fidelerin yeșil aksamı ile kök ve kök boğazında olușturduğu belirtilere dayanarak 75 izolat patojen olarak saptanmıșlardır. Patojenik reaksiyon veren izolatların uygulandığı bitkilerde inokulasyonun beșinci gününden itibaren önce kotiledon yapraklarında daha sonra gerçek yapraklarında sararma ve solgunluk belirtileri gözlemlenmiștir. Birkaç gün içerisinde bu belirtileri gösteren bitkilerin bazıları hızla solarak ölmüșlerdir. Ölmeyen bitkilerde ise zamanla yeni yaprak olușumu durmuș bu bitkiler kontrole oranla daha kısa kalmıșlardır. Ayrıca bu bitkilerin kök ve kök boğazında koyu renkli lezyon olușumunun yanısıra gövdede iletim demetleri boyunca kahverengileșmeler gözlemlenmiștir. Kontrol bitkilerinde ve bu test sonucu patojen olmadığı belirlenen II0 izolatın inokule edildiği bitkilerde herhangi bir hastalık belirtisi saptanmamıștır. Patojenisite testinde patojen izolatların olușturduğu hastalığın șiddetlerini belirlemek üzere fidelerin gövdeleri boyunca alınan kesitlerinde iletim demetlerinde olușan kahverengi hattın uzunlukları ölçülmüștür. Bu uzunlukların 0-5 skalasına göre elde edilen değerlerinin Tawsend Heuberger formülüne göre hastalık yüzdeleri (hastalık șiddeti) hesaplanmıștır. Test sonucu patojen olduğu saptanan 75 adet izolatın meydana getirdikleri hastalığın ortalama hastalık șiddeti değerleri \% I3 ile \%100 arasında değișmiștir. Bu izolatlardan 10 adeti \% 100 hastalık șiddetine neden olarak oldukça virülent bulunmușlardır (Çizelge 3).

Çizelge 3. Aydın'ın farklı ilçelerinden elde edilen Fusarium oxysporum f.sp. niveum izolatlarının sayısı ve virülenslik testlerinde olușturdukları hastalık șiddeti aralıkları

\begin{tabular}{lcc}
\hline Illçeler & İolat Sayısı & Hastalık Șiddeti Aralığı (\%) \\
\hline Koçarlı & 21 & $15-100$ \\
Çine & 17 & $13-100$ \\
Söke & 14 & $15-100$ \\
Bozdoğan & 8 & $18-100$ \\
Merkez & 6 & $17-67$ \\
Yenipazar & 4 & $22-100$ \\
Sultanhisar & 3 & $15-100$ \\
Incirliova & 1 & 84 \\
Nazilli & 1 & 24
\end{tabular}

Patojenisite testi sonucu patojen olarak bulunan 75 izolatın Fusarium oxysporum olduğunu netleștirmek için bir kez de CLA ortamında olușan yapılarının mikroskobik incelenmesi sonucu 73 izolatın F. oxysporum özelliklerine sahip olduğu belirlenmiștir. Morfolojik yapılarının özelliklerine göre $F$. oxysporum olarak tanısı yapılan 73 izolatın dıșında Çine ve Bozdoğan ilçelerinden elde edilen birer izolatın $F$. oxysporum olmadığı saptanmıștır. Patojenisite testinin ardından CLA'da da Fusarium oxysporum olarak tanılanan 73 izolatın bir kez de diğer kabakgiller olan kavun, kabak ve hıyarda patojen olup olmadığı test edilmiștir. Bu çalıșmada hiçbir izolatın kontrol olarak kullanılan Sugar Baby karpuz çeșidinde sergilediği sararma, solgunluk veya ölüm gibi hastalık belirtilerini diğer kabakgillerde yapmadığı gözlemlenmiștir. Buna ek olarak inokulasyondan bir ay sonra karpuz bitkilerinin kök/kök boğazında olușan lezyonlara ve iletim demetlerinde renk değișikliği yani kahverengileșmelere de rastlanmamıștır. Bu nedenle çalıșmamızda kavun, hıyar ve kabak bitkilerinde hastalık olușturmadığı belirlenen 73 izolat net olarak Fusarium oxysporum f.sp. niveum olarak tanılanmıștır. Yapılan bu tanılamalar sonucunda Aydın ilinde örnekleme yapılan ilçelerin karpuz alanlarında hastalık etmeni olarak bulunan $F$. oxysporum'un FON olduğu ortaya konmuștur. İlçeler arasında en fazla FON izolatı (2I adet) Koçarlı ilçesinden elde edilirken, karpuz üretimi ile ilk sırada yer alan Çine 16 FON izolatı ile ikinci sırada yer almıștır. Bu ilçeleri sırası ile Söke (I4 adet), Bozdoğan (7 adet), Merkez (6 adet), Yenipazar (4 adet) ve Sultanhisar (3 adet) takip etmiștir. Illçeler arasında en az FON izolatı birer izolat ile İncirliova ve Nazilli ilçelerinden elde edilmiștir (Çizelge 3).

Aydın ilinde Fusarum oxysporum f.sp. niveum'un Olușturduğu Hastalığın Bulunma Oranı

Karpuzlarda solgunluk ve kurumaların Aydın ilinde yaygınlığını belirlendikten sonra hastalıklı bitki örneklerden izole edilen ve FON olarak tanısı yapılan etmenin neden olduğu Fusarium solgunluğu hastalığının Aydın'da bin tonun üzerinde karpuz üretimi olan ilçelerinin hepsinde farklı oranlarda bulunduğu saptanmıștır. Bu ilçelerde örnekleme yapılan 7I karpuz tarlasının 45 'inde FON izolatı elde edilerek bu tarlaların FON ile bulașık olduğu teyit edilmiștir. Çizelge 4'de görüldüğü üzere FON izolatı elde edilen bu 45 tarlada hastalığın bulunma oranının \%0.17-12 arasında değiștiği saptanmıștır. Koçarlı ilçesinde örnekleme yapılan 20 tarlanın I4'ünde FON izolatı elde edilirken hastalığın bulunma oranı \%0.20 ile \%0.9। arasında değișmiștir. Çine ilçesinde örneklerin alındığı 16 tarladan 12'sinde FON izolatı elde edilmiș olup, hastalık bulunma oranı $\% 0.20$ - \% 12 olarak hesaplanmıștır. Bu ilçede bulunan iki tarla \%4 ve \% 12 lik değerler ile hastalığın en yoğun olduğu tarlalar olarak belirlenmiștir. Merkez ilçeden 2, İncirliova ve Nazilli ilçelerinde birer tarladan alınan örneklerin hepsinden FON izolatı elde edilmiș olup, hastalık bulunma oranları \%।.33 altında kalmıștır. Çukurova Bölgesi'nde Yücel ve ark. (1999) 1993-1994 yılları arasında yapmıș oldukları araștırmada karpuzda Fusarium solgunluk hastalı̆̆ının bulunma oranı Adana ilinde \%।6.2 oranında saptanırken ve Mersin ilinde bu oranın \%23.I olduğu bildirilmiștir. Kurt ve ark., (2005), Doğu Akdeniz ve Güneydoğu 
Çizelge 4. Aydın' da önemli karpuz üreticisi ilçelerde karpuz solgunluk hastalığının bulunma oranı

\begin{tabular}{|c|c|c|c|c|c|}
\hline İlçeler* & $\begin{array}{c}\text { Tarladaki } \\
\text { Hasta Bitkilerin } \\
\text { Oranı }^{\times} \\
(\%)\end{array}$ & $\begin{array}{l}\text { Hasta Bitki } \\
\text { Örneği } \\
\text { Sayısı }^{b}\end{array}$ & $\begin{array}{l}\text { FON İzole Edilen } \\
\text { Bitki Örneği } \\
\text { Sayısı }^{\text {a }}\end{array}$ & $\begin{array}{l}\text { FON İzole Edilen } \\
\text { Bitkilerin Oranı } \\
\text { (\%) }\end{array}$ & $\begin{array}{l}\text { FON'un Hastalandırdığı** } \\
\text { Bitkilerin Bulunma Oranı }{ }^{z} \\
\text { (\%) }\end{array}$ \\
\hline \multirow{20}{*}{ Koçarlı } & 0.01 & 2 & $\mathrm{I}$ & 0.50 & 0.50 \\
\hline & 0.03 & 6 & I & 0.17 & 0.50 \\
\hline & 0.04 & 6 & I & 0.17 & 0.67 \\
\hline & 0.01 & 4 & 2 & 0.50 & 0.50 \\
\hline & 0.03 & 5 & 1 & 0.20 & 0.60 \\
\hline & 0.01 & 5 & 2 & 0.40 & 0.40 \\
\hline & 0.02 & 5 & 0 & 0.00 & 0.00 \\
\hline & 0.01 & 3 & I & 0.33 & 0.33 \\
\hline & 0.06 & 12 & 0 & 0.00 & 0.00 \\
\hline & 0.01 & 6 & 4 & 0.67 & 0.67 \\
\hline & 0.01 & 3 & 0 & 0.00 & 0.00 \\
\hline & 0.01 & 5 & I & 0.20 & 0.20 \\
\hline & 0.01 & 4 & 2 & 0.50 & 0.50 \\
\hline & 0.01 & 5 & 0 & 0.00 & 0.00 \\
\hline & 0.04 & 5 & 0 & 0.00 & 0.00 \\
\hline & 0.01 & 3 & 1 & 0.33 & 0.33 \\
\hline & 0.01 & 3 & 0 & 0.00 & 0.00 \\
\hline & 0,01 & 4 & I & 0.25 & 0.25 \\
\hline & 0.01 & 4 & I & 0.25 & 0.25 \\
\hline & 0.05 & 11 & 2 & 0.18 & 0.91 \\
\hline \multirow{16}{*}{ Çine } & 0.01 & 5 & I & 0.20 & 0.20 \\
\hline & 0.02 & 6 & 1 & 0.17 & 0.33 \\
\hline & 0.01 & 5 & I & 0.20 & 0.20 \\
\hline & 0.02 & 5 & I & 0.20 & 0.40 \\
\hline & 0.02 & 5 & I & 0.20 & 0.40 \\
\hline & 0.01 & 5 & 0 & 0.00 & 0.00 \\
\hline & 0.10 & 10 & 2 & 0.20 & 2.00 \\
\hline & 0.60 & 15 & I & 0.07 & 4.00 \\
\hline & 0.90 & 15 & 2 & 0.13 & 12.00 \\
\hline & 0.02 & 4 & I & 0.25 & 0.50 \\
\hline & 0.01 & 3 & I & 0.33 & 0.33 \\
\hline & 0.01 & 5 & 2 & 0.40 & 0.40 \\
\hline & 0.01 & 6 & 2 & 0.33 & 0.33 \\
\hline & 0.01 & 4 & 0 & 0.00 & 0.00 \\
\hline & 0.04 & 7 & 0 & 0.00 & 0.00 \\
\hline & 0.01 & 6 & 0 & 0.00 & 0.00 \\
\hline \multirow{14}{*}{ Söke } & 0.06 & 10 & 2 & 0.20 & 1.20 \\
\hline & 0.04 & 10 & 0 & 0.00 & 0.00 \\
\hline & 0.01 & 5 & 1 & 0.20 & 0.20 \\
\hline & 0.01 & 3 & 0 & 0.00 & 0.00 \\
\hline & 0.02 & 10 & 5 & 0.50 & 1.00 \\
\hline & 0.01 & 7 & 0 & 0.00 & 0.00 \\
\hline & 0.01 & 6 & 0 & 0.00 & 0.00 \\
\hline & 0.01 & 4 & 2 & 0.50 & 0.50 \\
\hline & 0.01 & 5 & 2 & 0.40 & 0.40 \\
\hline & 0.03 & 9 & I & 0.11 & 0.33 \\
\hline & 0.01 & 3 & 0 & 0.00 & 0.00 \\
\hline & 0.01 & 8 & 0 & 0.00 & 0.00 \\
\hline & 0.01 & 5 & 0 & 0.00 & 0.00 \\
\hline & 0.10 & 10 & I & 0.10 & 1.00 \\
\hline
\end{tabular}

* 1000 tonun üzerinde karpuz üretimi yapıldığı belirtilen ilçeler (Anonim,2009)

**Hastalık bulunma oranı: $z=(x . y) 100 \quad(y=a / b)$ 
Çizelge 4'ün devamı

\begin{tabular}{|c|c|c|c|c|c|}
\hline İlç̧eler* & $\begin{array}{c}\text { Tarladaki } \\
\text { Hasta Bitkilerin } \\
\text { Oranı }{ }^{\times} \\
(\%)\end{array}$ & $\begin{array}{l}\text { Hasta Bitki } \\
\text { Örneği } \\
\text { Sayısı }^{\text {b }}\end{array}$ & $\begin{array}{l}\text { FON İzole Edilen } \\
\text { Bitki Örneği } \\
\text { Sayısı }^{\mathrm{a}}\end{array}$ & $\begin{array}{l}\text { FON İzole Edilen } \\
\text { Bitkilerin Oranı }{ }^{y} \\
\text { (\%) }\end{array}$ & $\begin{array}{c}\text { FON'un Hastalandırdığı** } \\
\text { Bitkilerin Bulunma Oranız } \\
(\%)\end{array}$ \\
\hline \multirow{8}{*}{ Bozdoğan } & 0.01 & 3 & I & 0.33 & 0.33 \\
\hline & 0.02 & 7 & 0 & 0.00 & 0.00 \\
\hline & 0.10 & 10 & 0 & 0.00 & 0.00 \\
\hline & 0.01 & 4 & I & 0.25 & 0.25 \\
\hline & 0.05 & 8 & 2 & 0.25 & 1.25 \\
\hline & 0.02 & 7 & 0 & 0.00 & 0.00 \\
\hline & 0.01 & 8 & 2 & 0.25 & 0.25 \\
\hline & 0.01 & 5 & I & 0.20 & 0.20 \\
\hline \multirow{9}{*}{ Sultanhisar } & 0.01 & 7 & 0 & 0.00 & 0.00 \\
\hline & 0.01 & 6 & I & 0.17 & 0.17 \\
\hline & 0.01 & 4 & 0 & 0.00 & 0.00 \\
\hline & 0.03 & 8 & I & 0.13 & 0.38 \\
\hline & 0.01 & 4 & 0 & 0.00 & 0.00 \\
\hline & 0.04 & 8 & I & 0.13 & 0.50 \\
\hline & 0.01 & 5 & 0 & 0.00 & 0.00 \\
\hline & 0.01 & 3 & 0 & 0.00 & 0.00 \\
\hline & 0.01 & 3 & 0 & 0.00 & 0.00 \\
\hline \multirow{2}{*}{ Merkez } & 0.02 & 10 & 4 & 0.40 & 0.80 \\
\hline & 0.02 & 3 & 2 & 0.67 & 1.33 \\
\hline İncirliova & 0.01 & 3 & I & 0.33 & 0.33 \\
\hline Nazilli & 0.02 & 6 & $\mathrm{I}$ & 0.17 & 0.33 \\
\hline
\end{tabular}

* 1000 tonun üzerinde karpuz üretimi yapıldığı belirtilen ilçeler (Anonim,2009)

**Hastalık bulunma oranı: $z=(x . y) 100(y=a / b)$

Anadolu illerinde 2004 yılında solgunluk belirtisi sergileyen bitkilerden alınan örneklerden izole ettikleri etmenlerin \%76'sının FON olduğunu saptamıșlardır. Bu bölgelerde karpuzda Fusarium solgunluğu bulunma oranı en fazla Diyarbakır (\%5ı.0) ilinde en az Mersin ilinde (\%।8.8) bulunduğunu kaydetmișlerdir. Aydın ìli karpuz üretim alanlarında belirlenen FON' un neden olduğu hastalık bulunma oranı sadece karpuz üretiminde önde gelen illerimizde yapılan çok az sayıdaki çalıșma ile karșılaștırıldığında hastalık bulunma oranının oldukça düșük olduğu görülmektedir.

\section{SONUÇ}

Dünyada karpuz üretiminde olușan verim kayıplarının en önemli nedenlerinden biri olarak gösterilen Fusarium oxysporum f.sp. niveum adlı toprak kökenli fungal patojenin Aydın ve ilçelerindeki karpuz üretim alanlarında olușturduğu karpuz Fusarium solgunluğunun yaygınlığı ve yoğunluğu belirlenmiștir. Karpuzlarda solgunluk ve kurumaların yaygınlığının belirlendiği Merkez, Çine, Koçarlı, Bozdoğan, Söke, Sultanhisar, Yenipazar, Nazilli, İncirliova ve Köșk ilçelerinde incelenen 132 tarladan 80 'inde bu belirtilerin bulunduğu karpuz bitkileri saptanmıștır. Adı geçen ilçelerde hastalık yaygınlı̆̆ı \%45-100 arasında değișmiş, olup solgunluk ve kuruma en yaygın olarak Koçarlı ilçesinde saptanmıștır. Aydın ilinde yaygınlığı belirlenen kuruma ve solgunlukların nedenlerinden biri olan FON'un olușturduğu karpuz Fusarium solgunluğunun bulunma oranı 1000 tonun üzerinde üretimi olan ilçelerde saptanmıștır. FON'un saptandığı 45 tarlada hastalık bulunma oranı \%0.17-12 arasında değișmekte olup, en yüksek bulunma oranı Çine ilçesinde yer alan bir üretim alanında belirlenmiștir. Yapılan sörveyler sırasında karpuzda solgunluk hastalığının bulunmadığı üretim alanlarının varlığı üretici açısından sevindirici bir durum olsa da bu alanlarda yapılan herhangi bir hata hastalık etmeninin temiz alanlara bulașmasına ve hızla yayılmasına neden olacaktır. Özellikle solgunluk hastalığının görülmediği üretim alanlarında kullanılacak olan tohum ve fide gibi üretim materyallerinin hastalıktan ari olduğundan emin olmak adına sertifikalı ürünlerin kullanılması birinci derecede önem arz etmektedir. Ayrıca FON'un toprak kaynaklı olması bu hastalık etmeninin tarımsal faaliyetler sırasında bulașık toprakla birlikte kolaylıkla temiz alanlara tașınabileceğini göstermektedir. Bu nedenle tarlada üretim sırasında kullanılan tüm araç ve gereçlerin temizliğine özen gösterilmelidir. Aynı zamanda karpuz üretim alanlarında sıkça karșılaștığımız ve hastalığın geniș alanlara yayılmasında önemli bir faktör olan karıkla sulama ișleminin yerine damla sulama sistemi tercih edilmeli ve kullanılan sulama suyunun temizliğine dikkat edilmelidir.

\section{TEȘEKKÜR}

Bu araștırma, Doktora çalıșmasının bir bölümü olup ZRF-I20I I proje kodu ile Adnan Menderes Üniversitesi Bilimsel Araștırma Projeleri tarafından maddi olarak desteklenmiștir. Adnan Menderes Üniversitesi Bilimsel Araștırma Projeleri Birimine katkılarından dolayı teșekkür ederiz.

\section{KAYNAKLAR}

Akdoğan M (1969) Research on the Chemical Control Method against Wilt Disease (Fusarium spp,) Occurring in Melons and Watermelons. Plant Protection Bulletin 9: 123-128.

Anonim (2009) Türkiye İstatistik Kurumu. http://www.tuik.gov.tr/ (Erișim Tarihi:01/06/2010)

Bora T, Özkut A (1972) A Preliminary Survey on the Occurrence of Fusarium Wilt of Watermelon in Ege Region of Turkey. Journal of Turkish Phytopathology I: 33-38. 
Egel DS, Martyn RD (2007) Fusarium Wilt of Watermelon and other Cucurbits. The Plant Health Instructor doi: 10.1094/PHI-I-2007-0I22-0I.

Ferreira SA, Boley RA (199I) Fusarium oxysporum f.s.p. niveum Wilt of Watermelon. http://www.extento.hawaii.edu/ (Erișim Tarihi: 10/02/20II)

Filiz N, Turhan G (199I) Karpuzlarda Fusarium Solgunluğu Etmenlerinin Irklarının Saptanması ve Karpuz Çeșitlerinin Reaksiyonları Üzerinde Araștırmalar. In: VI. Türkiye Fitopatoloji Kongresi, 7-II Ekim I99I, İzmir, II5-II9.

Geçioğlu Erincik B, Döken MT (2017) The Determination of Reaction of Some Watermelon Cultivars to the Races of Fusarium oxysporum f.sp. niveum. The Journal of Turkish Phytopathology (46): 33-4I.

Karaca I, Qureshi SH (1979) Ege Bölgesinde Karpuz Fusarium Solgunluğu Etmeninin Patojenisitesi, Irkları, Hastalık ile Makrobesin Elementleri ve Pektolitik Enzim ilișkileri Üzerinde Araștırmalar. Türkiye Bilimsel ve Teknik Araștırma Kurumu Raporu (Proje No: TOAG-35I). Ankara.

Kuniyasu K (1980) Seed Transmission of Fusarium Wilt of Bottle Gourd, Lagenaria siceraria, Used as a Root Stock Of Watermelon. Japan Agricultural Research Quarterly 14: 157-162.

Kurt Ș, Derviș S, Soylu EM, Tok FM, Baran B, Soylu S ve Yetișir H (2005) Doğu Akdeniz ve Güneydoğu Anadolu Bölgelerinde Karpuz Solgunluk Hastalığı Etmenlerinin Yaygınlıkları ve Patojenisiteleri. In: Gap 4. Tarım Kongresi Bildirileri, 2I-23 Eylül 2005, Șanlıurfa, I 385-I390.

Kurt S, Dervis S, Soylu EM, Tok FM, Yetisir H ve Soylu S (2008) Pathogenic Races and Inoculum Density of Fusarium
GEÇIOĞLU ERINCIK B, DÖKEN M T oxysporum f.sp. niveum in Commercial Watermelon Fields in Southern Turkey. Phytoparasitica 36(2): 107-II6.

Latin RX, Snell SJ (1986) Comparison of methods for inoculation of muskmelon with Fusarium oxysporum f. sp. melonis. Plant Disease 70: 297-300.

Leslie JF, Summerell BA (2006) The Fusarium Laboratory Manual. Blackwell Publishing, lowa, USA.

Martyn RD, McLaughlin RJ (1983) Effects of Inoculum Concentration on the Apparent Resistance of Watermelon to Fusarium oxysporum f. sp. niveum. Plant Disease 67: 493495.

Martyn RD (1996) Fusarium Wilt of Watermelon. In: Zitter TA, Hopkins DL and Thomas CE (eds). Compendium of Cucurbit Diseases, The American Phytopatological Society, St. Paul, MN, I3-I4.

Qureshi SH, Yıldı M (1982) A study of Pathogenicity and Pathogenic Races of Fusarium Wilt of Watermelon and the Effect of Macroelements Nutrition of Host on Disease Development in Relation to the Production of Pectolytic Enzymes. Journal of Turkish Phytopathology I I: 15-32.

Yücel S, Pala H, San N ve Abak K (1999) Determination of Fusarium oxysporum f.sp. niveum Races in the Eastern Mediterranean Region of Turkey and Response of Some Watermelon Genotypes. Acta Horticulturae 492: 349-353.

Zhou XG, Everts KL (2007) Characterization of a Regiona Population of Fusarium oxysporum f. sp. niveum by Race, Cross pathogenicity, and Vegetative Compatibility. Phytopathology 97: 46I-469.

Zhou XG, Everts KL, Bruton BD (2010) Race 3, a New and Highly Virulent Race of Fusarium oxysporum f. sp. niveum Causing Fusarium Wilt in Watermelon. Plant Disease 94: 92-98. 
